\title{
Szerkesztői kommentár
}

Selye János nevét fóleg a biológiai stresszreakcióval kapcsolatban ismerik világszerte, és még szakmai körökben is kevesen tudják, hogy Selye sokkal több, a mai napig érvényes felfedezést tett, amelyeket körülbelül 70 éve írt le néhány, mai szemmel értékelve történelmi cikkben olyan híres nemzetközi tudományos folyóiratokban, mint például a Nature, Science, Lancet, Endocrinology. E felfedezések 70 éves évfordulóján a Magyar Tudományos Akadémián két nagyobb szimpóziumot rendeztünk: 2013-ban angol nyelven, amin főleg Selye egykori PhD-diákjai és munkatársai tartottak előadásokat, valamint 2014 novemberében „A stresszen túl: Selye János kevésbé ismert kutatásai” címú szimpóziumot a „Magyar Tudomány Ünnepe” keretein belül. Ez utóbbi szimpó- ziumon Vécsei László, Somogyi Árpád és Szabó Sándor akadémikusok elnökletével főleg hazai magyar szakértők tartottak előadást. E tematikus lapszámot az elhangzott előadások alapján állítottuk össze. A szimpózium szervezői külön köszönetet mondanak az Orvosi Hetilap szerkesztőségének a megjelenés lehetőségéért.

Szabó Sándor $d r$. Gyires Klára dr. a lapszám vendégszerkesztői

Somogyi Árpád dr. Vécsei László dr. a lapszám társvendégszerkesztői 